\title{
Fish-habitat associations in New Zealand: geographical contrasts
}

\author{
Russell G. Cole ${ }^{1, *}$, Niki K. Davey ${ }^{1}$, Glen D. Carbines ${ }^{2,4}{ }^{,}$Rob Stewart ${ }^{3}$ \\ ${ }^{1}$ National Institute of Water and Atmospheric Research Ltd., PO Box 893, Nelson 7040, New Zealand \\ ${ }^{2}$ National Institute of Water and Atmospheric Research Ltd., PO Box 6414, Dunedin 9016, New Zealand \\ ${ }^{3}$ National Institute of Water and Atmospheric Research Ltd., PO Box 14-901, Wellington 14901, New Zealand \\ ${ }^{4}$ Present address: Saltwater Science Ltd., PO Box 89234, Torbay, North Shore, Auckland 0742, New Zealand
}

\begin{abstract}
Relationships between fishes and habitat variables were assessed by transect counts and manipulative experiments on subtidal rocky reefs in 3 poorly known regions of New Zealand (eastern Bay of Plenty, western Cook Strait, and eastern Stewart Island). Canonical correspondence analysis successfully described associations between fishes and habitat features. Depth, topographic complexity, and macroalgal canopy cover were most consistently identified as influencing fish abundance. Experimental macroalgal clearances at eastern Bay of Plenty (short term) and western Cook Strait (longer term) indicated that Notolabrus celidotus used areas comprising macroalgal canopy more than cleared areas, whereas Parapercis colias and $N$. fucicola were more active in cleared areas. Effects of canopy clearance on fish activity were most obvious in summer at Cook Strait. Orthogonal manipulations of canopy and topographic complexity at a distant site (Tasman Bay) produced similar results for 2 species, indicating geographic generality of habitat models for $N$. celidotus and P. colias.
\end{abstract}

KEY WORDS: Temperate reef fishes $\cdot$ Macroalgae $\cdot$ New Zealand $\cdot$ Experiments $\cdot$ Topographic complexity

\section{INTRODUCTION}

Fishes are frequently large and conspicuous components of the fauna of temperate reefs. They are important because of their abundance and biomass, their value to fisheries (e.g. Smale \& Buxton 1985), and because their feeding may influence other organisms (e.g. Ojeda \& Dearborn 1991). They are also strongly affected by direct and indirect human activities (Halpern 2003). Fishes are often associated with particular features of their environment (e.g. Gust et al. 2001, Francis et al. 2002), rendering habitat-specific management viable (e.g. Peterson et al. 2000). An understanding of fish-habitat linkages constitutes important primary information that can be used to predict occurrences of fishes, and can inform human activities.

Habitat features that structure marine reef-fish assemblages include lithic elements such as sand, rocks, and crevices, and biotic elements such as macroalgae and corals (reviews in Ebeling \& Hixon 1991, Jones \& McCormick 2002). These links have been demonstrated experimentally in some situations (e.g. Pérez-Matus \& Shima 2010). However, fish-habitat linkages are poorly understood for marine fishes in most regions, and have not been described for rocky reefs in many temperate regions. In order to better manage rocky reefs and their faunas, an improved understanding of the inter-relationships between fishes and habitats is required. Sound 
knowledge of fish-habitat associations is necessary to predict the effects of anthropogenic disturbances - to both lithic (e.g. sediment disposal, artificial reef creation) and biological (e.g. harvesting of macroalgae and echinoids) elements - on reef communities (review in Turner et al. 1999; Jones et al. 2004).

Understanding links between fishes and habitats typically starts with descriptions of broad-scale patterns in both. Depth is the most obvious gradient along which reef fish assemblages may vary, and numerous studies have described depth-related patterns in abundances of fishes (e.g. Nagelkerken et al. 2000, Ruitton et al. 2000). However, many habitat constituents (e.g. geomorphological substrata) and environmental parameters (e.g. light, wave action) also vary along depth gradients, and more detailed analyses and experiments have been used to dissect depth-related patterns. Characteristics of lithic elements, especially topographic complexity, may influence reef fish assemblages, with particular fishes being associated with primary strata that are either rugose or have low profiles (Jones 1988, Tupper \& Boutilier 1997). Topographic complexity may vary at a range of spatial scales, and on temperate rocky reefs is primarily a function of geology. The primary effects of topographic complexity lie in providing shelter from predators (e.g. Forsterygion varium; Connell \& Jones 1991) and sites for laying eggs (Parma alboscapularis; Thompson 1981). In many situations, topographic complexity decreases at greater depths.

In rocky reef environments, fish assemblages frequently differ between areas with and without macroalgae, which act as the major biotic habitat-formers (e.g. Choat \& Ayling 1987, Levin \& Hay 1996). Macroalgal stands not only provide shelter from predators (Johnson 2006), but are occupied by abundant small invertebrates that are associated with the fronds (Edgar \& Moore 1986), are highly productive (Taylor 1998), and frequently form important components of the diet of small or young fish (Jones 1988). Macroalgal assemblage composition varies with broad-scale oceanography, wave action, and along depth gradients via direct processes such as nutrient supply, wave dislodgement, and light limitation (Schiel \& Foster 2006). The intensity of grazing on macroalgae may also vary along those gradients, leading to finer-scale variation in macroalgal cover (Jones \& Andrew 1990), and be associated with central point foragers, such as diadematoid sea urchins and territorial pomacentrids of the genus Parma (Jones \& Andrew 1990). Thus, abundances of fishes are influenced by macroalgae at spatial scales from regional to local.

Jones (1988) reviewed patterns of abundances of reef fishes in northeastern New Zealand and described patterns among locations, within locations, and within sites. He noted that variability among sites ( $<5 \mathrm{~km}$ separation) and among habitats within sites was frequently as great as that at geographical $(>100 \mathrm{~km})$ scales. Numerous associations were identified between abundances of fishes and habitat features within sites, most particularly, with topographic complexity and abundances of macroalgae (Jones 1988). Experimental manipulations indicate that topographic complexity (Connell \& Jones 1991) and turf and macroalgal occurrence (Kingett \& Choat 1981, Jones 1984, Choat \& Ayling 1987) influence the local abundance of reef fishes in northeastern New Zealand. Elsewhere in New Zealand, far fewer associations have been examined in detail (but see PérezMatus \& Shima 2010), although it is known that abundances of common fishes vary among depth strata (R. G. Cole et al. unpubl. data). Both the fauna of fishes (Francis 1996, Schiel \& Hickford 2001) and the macroalgal flora (Schiel 1990) in more southern regions are distinct from those of more intensively studied regions such as northeastern New Zealand.

We analyzed underwater visual survey data for abundances of fishes and associated habitat information gathered in 3 widely spread regions of coastal New Zealand. We supported this with experimental manipulations of macroalgal canopies in 2 of the 3 regions. Our hypotheses were that fish abundances would vary with depth and habitat variables.

\section{MATERIALS AND METHODS}

\section{Fish transect surveys}

Reef fish populations were surveyed in the austral summers of 2001 and 2002 with a hierarchical sampling design comprising regions, localities, sites, and transects, and habitat/depth strata as a fixed factor crossed with sites (R. G. Cole et al. unpubl.). Thirtytwo sites were studied in each of 3 poorly known regions: (1) eastern Bay of Plenty $\left(38^{\circ} \mathrm{S}, 177^{\circ} \mathrm{E}\right)$, sampled February 2002; (2) western Cook Strait $\left(41^{\circ} \mathrm{S}\right.$, $173^{\circ} \mathrm{E}$ ), sampled February 2001; and (3) eastern Stewart Island $\left(47^{\circ} \mathrm{S}, 168^{\circ} \mathrm{E}\right)$, sampled March 2001). In each region, the 32 sites were grouped into localities $(\mathrm{n}=8)$ with 4 randomly chosen sites in a locality being sampled on a single day. Complete randomization of order of sampling sites was not practical, but 
each of the 3 regions was surveyed over a period of $\sim 10 \mathrm{~d}$, which is a shorter duration than that over which seasonal migration or ontogenetic shifts would be expected to occur. We were unable to allocate transects to biological habitats explicitly a priori, as generally we had not visited the sites before. Transects were allocated in situ across the reef within a site, with 5 to 10 transects site ${ }^{-1}$, depending on depth and sea conditions. There were 4 depth/habitat strata: 0-8 m, 8-16 m, 16-24 m, and lower reef edge. No attempt was made to balance the sampling design, but we generally sampled all strata to a maximum depth of $24 \mathrm{~m}$. Where reef extended beyond $24 \mathrm{~m}$, reef edge was not sampled, and if reef edge occurred at $12 \mathrm{~m}$ depth, deeper strata were unsampled. A typical allocation was 2 transects at reef edge, 3 at $8-16 \mathrm{~m}$, and 3 at $0-8 \mathrm{~m}$. Reef fishes were counted (by R. G. Cole and G. D. Carbines) in $30 \mathrm{~m} \times$ $4 \mathrm{~m}$ tape transects, as the tape was laid, with a $10 \mathrm{~m}$ uncounted lead-in. Transect dimensions were chosen (after pilot studies in the Cook Strait region) to be practical in the field, be robust to variable underwater visibility, and permit adequate replication within a dive.

Habitat features were quantified on the same transects as fish counts. Random $5 \mathrm{~m}$ sections $(\mathrm{n}=2)$ of each $30 \mathrm{~m}$ fish transect were quantified as follows. The diver recorded (in $\mathrm{m}$ ) the bottom depth and the depth at the top of the canopy; canopy height was calculated as the difference between the 2 values. Substratum characteristics were recorded as presence or absence of bedrock, boulders, cobbles, gravel, shell rubble, sand, or mud. Topographic complexity was recorded on a qualitative scale from 1 to 5 , where 1 was flat, and 5 comprised pinnacles and channels. The canopy-forming macroalgal species were then recorded, along with their estimated cover on a 10-point qualitative scale within the $5 \mathrm{~m}$ transect. Sub-canopy macroalgal species were recorded on the same scale. Codes for habitat variables are given in Table 1. The same 2 divers (N. K. Davey and R. Stewart) carried out all habitat assessments in all 3 regions. Random sub-samples were used because it was impractical to quantify some variables (e.g. canopy height) at the scale of the entire transect.

\section{Manipulative experiments}

We carried out a series of experiments manipulating the abundances of macroalgae at several sites. Macroalgal clearance experiments were established in the 3 surveyed regions to establish whether the associations between macroalgae and fishes identified in the surveys (i.e. observed in multivariate analyses) were causal. In subsequent years, budgetary constraints made continued experimentation with macroalgal canopies intractable, and we worked locally.

\section{Macroalgal clearance experiments}

The main experiment was carried out over 8 mo at Port Hardy $\left(40^{\circ} 42^{\prime} \mathrm{S}, 173^{\circ} 57^{\prime} \mathrm{E}\right.$, at 9 to $11 \mathrm{~m}$ depth) in western Cook Strait, and an additional short-term experiment was done at Rurima Shoals $\left(37^{\circ} 50^{\prime} \mathrm{S}\right.$, $176^{\circ} 53^{\prime} \mathrm{E}, 10 \mathrm{~m}$ depth) in the Bay of Plenty. (A parallel short-term experiment established at Stewart Island was unable to be resampled because of poor visibility.)

Port Hardy. Ten $10 \times 10 \mathrm{~m}$ quadrats were initially marked out in July 2002. Reefs at 9 to $11 \mathrm{~m}$ depth had canopies of Carpophyllum flexuosum (to $2 \mathrm{~m}$ high)

Table 1. Habitat variables and codes recorded in surveys. Codes in parentheses are used in Figs. 1 to 3

\section{(a) Lithic (i.e. geological) variables}

Bottom depth (Botdepth), depth at top of canopy (Candepth), and canopy height (Canht = Botdepth - Candepth); Presence or absence of mud (M), sand (S), shell rubble (SR), gravel (G), cobbles (CB), boulders (BD), and bedrock (BR); Topographic complexity (Topcomp) on a qualitative scale from 1 (flat) to 5 (pinnacles and channels)

(b) Macroalgal variables, each on a qualitative 10-point scale from 1 (sparse cover) to 10 (very dense canopy), as well as presence $(0.1)$ or absence $(0)$

Asparagopsis sp. (AG), Boltenia pachydermatina (ST), Cystophora spp. (C), Carpomitra sp. (CP), Codium sp. (CD), Carpophyllum flexuosum (CF), Cladhymenia oblongifolia (CH), Carpophyllum maschalocarpum (CM), Colpomenia sp. (CO), Corallines (PP), Cystophora platylobium (CPB), Cystophora distenta (CPD), Cystophora retroflexa (CR), Cystophora torulosa (CT), Caulerpa sp. (CU), Desmarestia sp. (DES), Delisea sp. (DP), Dictyota spp. (DT), Durvillaea spp. (DU), Ecklonia radiata (ER), Gigartina sp. (GG), Glossophora sp. (GO), Hymenena sp. (HM), Halopteris sp. (HP), Landsburgia sp. (LB), Lessonia variegata (LS), Marginariella boryana (MB), Macrocystis pyrifera (MP), Pterocladia sp. (PT), Spatoglossum chapmani (SP), Sargassum spp. (SS), Ulva lactuca (UL), Xiphophora spp. (XI), Zonaria spp. (ZN) 
and Ecklonia radiata (to $1 \mathrm{~m}$ high), with C. flexuosum dominating. Overall percent cover of macroalgae in quadrats prior to clearance was $70 \pm 3 \%$, and canopy height was $1.3 \pm 0.05 \mathrm{~m}$ (means $\pm \mathrm{SE}_{;} 1 \mathrm{~m}^{2}$ sampling quadrats, $\mathrm{n}=5$ per $10 \times 10 \mathrm{~m}$ quadrat, total $\mathrm{n}=50$ ). The treatments (cleared or uncleared) were established in pairs, so that the canopy of 1 quadrat of each of the 5 pairs was cleared, and the macroalgal canopy of the other quadrat of each pair remained intact. All macroalgae in clearance-treatment quadrats were removed by severing them just above the holdfast in late July 2002. C. flexuosum floated to the surface, and E. radiata dispersed from the clearances in swell; no macroalgae remained during postclearance sampling of fishes.

Fish observations were made in each of the 10 quadrats once before and twice after clearing the canopy. In each $100 \mathrm{~m}^{2}$ quadrat, observation quadrats were placed in the central portion, marked out with a transect tape. Visits by fish to this $2 \times 2 \mathrm{~m}$ area of seabed were recorded during a $10 \mathrm{~min}$ observation period. Triplefins were not counted because it was not practical to quantify them at the same time as larger reef fishes. Each time a fish entered the observation quadrat by crossing the tape, its total length was estimated to the nearest centimeter. Because individual fish could not be identified, repeated visits of fish to the quadrat were possible, and our data measure fish activity (as do those of Choat \& Ayling 1987, for example). On each of the 3 sampling occasions, we also counted fish along transects in the cleared areas (at depths of 8 to $13 \mathrm{~m}$ ). Counts were done in the same way as the main sampling program $(30 \mathrm{~m} \times 4 \mathrm{~m}$, 1-way transects, $10 \mathrm{~m}$ uncounted lead-in), but sample sizes varied (6 in the July 2002 counts, 8 in August 2002 and October 2002).

Finally, in February 2003, we relocated 2 of the cleared quadrats at Port Hardy, and carried out another set of observations. Each of 2 divers (N. K. Davey and R. Stewart) made 1 non-contemporaneous 10 min observation on each quadrat. We made observations in nearby macroalgal stands, rather than attempting to relocate the same observation quadrats for the uncleared controls, because of time constraints.

Rurima Shoals. In March 2003, we established a short-term clearance experiment, by marking out and clearing Ecklonia radiata canopy in two $10 \times$ $10 \mathrm{~m}$ squares, and comparing observations in the centers of the clearances (as for Port Hardy) with similar observations in adjacent uncleared macroalgal canopies. Because we had to collect fish for addi- tional experiments, observations were only made after the clearances were established. Each of 2 divers (N. K. Davey and R. Stewart) made one $10 \mathrm{~min}$ observation on each quadrat. Hence, 2 observations were made on each of 2 experimentally cleared quadrats, and on adjacent uncleared areas.

Macroalgal and boulder manipulation

Tasman Bay coasts are dominated by barrens habitat, and reefs are topographically complex, with areas of boulders and rugose bedrock beneath steep cliffs, but large areas of platform reef. Prior New Zealand experiments had shown both topographic complexity (Connell \& Jones 1991) and macroalgal canopies (Choat \& Ayling 1987) to be important to fish. Furthermore, boulders covered with macroalgae on a pavement of barrens characterize shallow macroalgal areas in northeastern New Zealand (Ayling 1978), and we had also observed boulder tops acting as islands of barrens in kelp forests (R. G. Cole pers. obs.). We therefore established an experiment manipulating the presence/absence of macroalgae and boulders orthogonally, from January 2008 to April 2009 at Cable Bay $\left(41^{\circ} 09^{\prime} \mathrm{S}, 173^{\circ} 25^{\prime} \mathrm{E}\right)$, near Nelson. The site comprised barrens habitat on a bedrock substratum of low complexity. Twelve experimental plots $(2 \times 2 \mathrm{~m})$ were established at depths of 8 to $14 \mathrm{~m}$. Plots were assigned orthogonal combinations of macroalgae (Carpophyllum flexuosum, the only common subtidal macroalga on the Tasman Bay coast) at a density similar to natural stands ( 20 fronds plot $^{-1}$ ) and boulders (both collected nearby), a mesh control for the method of attaching macroalgae to boulders, and an unmanipulated control treatment ( 4 treatments, $\mathrm{n}=3$ quadrats treatment $\left.{ }^{-1}\right)$. Divers made 15 min observations of quadrats ( 1 per plot) on 2 April 2009, and recorded the number of visits by fish to the plots, and their length. Re-entries to the plot following departures were recorded as new visits. Underwater visibility at the site was $\sim 6 \mathrm{~m}$ at the time of observations.

\section{Statistical analysis}

Data for each survey region were analyzed separately. Multivariate ordinations were used to identify links between habitat features and abundances of fishes. Initially we carried out canonical correspondence analysis (CCA) between reef-associated spe- 
cies and environmental variables. We included all reef-associated fishes in the analyses, but eliminated some uncommon (total $<10$ ind. region $^{-1}$ ) species from plots for clarity of display.

For the survey data from eastern Bay of Plenty and western Cook Strait (no barrens were recorded at Stewart Island), we also calculated mean densities of fish within barrens (macroalgal cover $=0$ ) and macroalgal (macroalgal cover $>0$ ) habitats.

No formal statistical tests of data from the habitat manipulations were undertaken because p-values from tests of point null hypotheses do not summarize evidence (Carver 1993, Cole \& McBride 2004, Gerrodette 2011); the data are plotted as mean $\pm \mathrm{SE}$, and trends are discussed.

\section{RESULTS}

\section{Fish transect surveys}

Bay of Plenty

CCA of abundances of 32 fishes and 22 habitat features identified 2 canonical variates, which accounted for $11 \%$ and $6 \%$ of the variation in the data set, respectively (Fig. 1a). CAN1 primarily separated 7 fish species that occurred in shallow water from other species with high positive values, whereas CAN2 strongly separated 5 fishes associated with the reef edge from a second group of 6 reef-associated species. Seven fishes that occurred in shallow water (Odax pullus, Aplodactylus arctidens, Girella tricuspidata, Chironemus marmoratus, Notolabrus fucicola, Notolabrus celidotus, and Cheilodactylus spectabilis) had high scores on CAN1 and low scores on CAN2 (Fig. 1a). Those species were associated with small values of bottom depth, occurrence of bedrock, and high covers of Pterocladia sp., Lessonia variegata, Carpophyllum maschalocarpum, and other fucalean macroalgae (Fig. 1b). Three other species (Parika scaber, Parma alboscapularis, and Kyphosus sydneyanus) exhibited similar trends, but less strongly. Five fishes (Upeneichthys lineatus, Parapercis colias, Caesioperca lepidoptera, Pagrus auratus, and Gymnothorax prionodon) were associated with sand, and had high positive scores on CAN2 (Fig. 1). A second grouping (Suezichthys aylingi, Notolabrus inscriptus, Nemadactylus macropterus, Bodianus unimaculatus, Coris sandageri, and Pseudolabrus miles) was positively associated with bottom depth and boulders (Fig. 1). Latridopsis ciliaris was strongly associated with high values of topographic complexity.
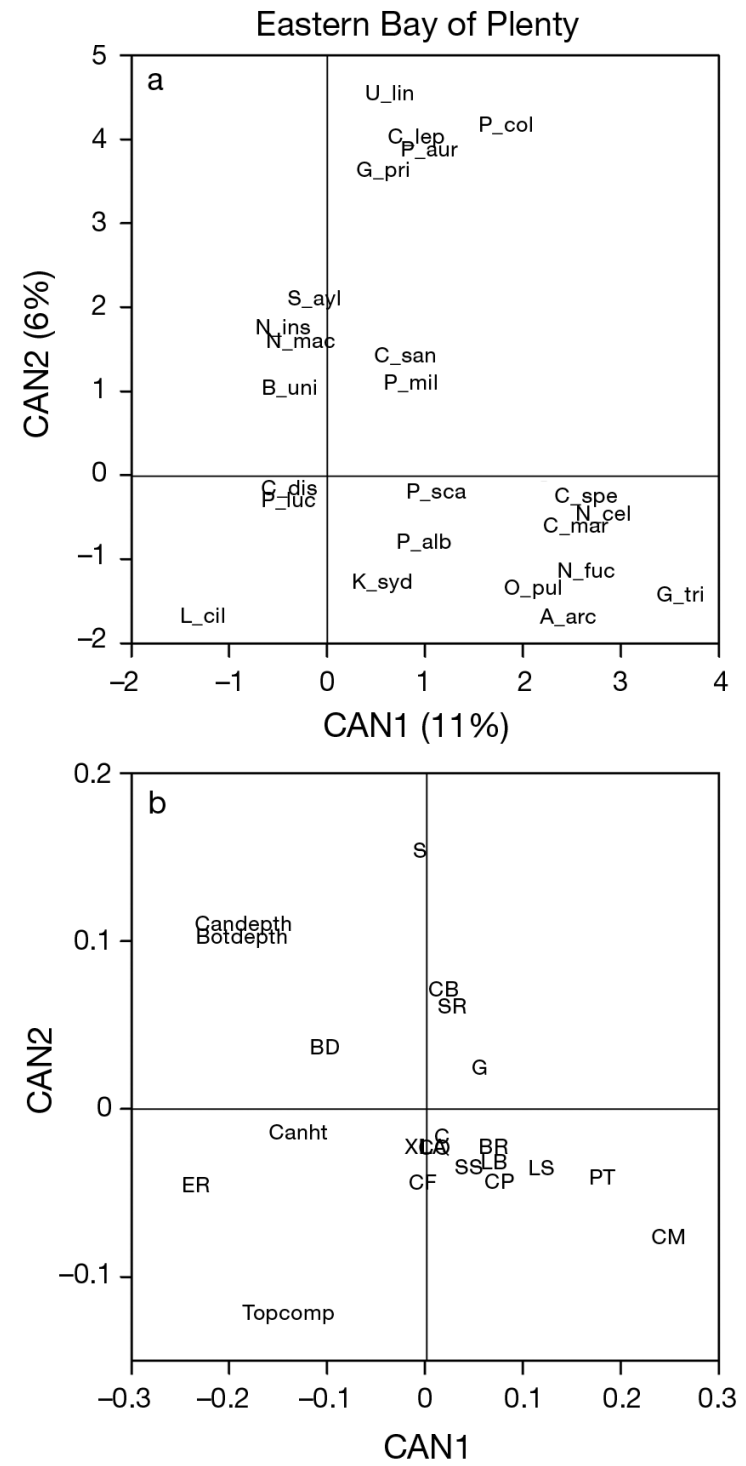

Fig. 1. Canonical correspondence analysis of (a) fishes and (b) habitat variables at eastern Bay of Plenty. A_arc: Aplodactylus arctidens; B_uni: Bodianus unimaculatus; C_dis: Chromis dispilus; C_lep: Caesioperca lepidoptera; C_mar: Chironemus marmoratus; C_san: Coris sandageri; C_spe: Cheilodactylus spectabilis; G_pri: Gymnothorax prionodon; G_tri: Girella tricuspidata; K_syd: Kyphosus sydneyanus; L_cil: Latridopsis ciliaris; N_cel: Notolabrus celidotus; N_fuc: Notolabrus fucicola; N_ins: Notolabrus inscriptus; N_mac: Nemadactylus macropterus; O_pul: Odax pullus; P_alb: Parma alboscapularis; P_aur: Pagrus auratus; P_col: Parapercis colias; $\mathrm{P}_{\text {_luc: Pseudolabrus luculentus }} \mathrm{P}_{-}$mil: Pseudolabrus miles; P_sca: Parika scaber; S_ayl: Suezichthys aylingi; U_lin: Upeneichthys lineatus. See Table 1 for substratum and biogenic habitat abbreviations

When all macroalgal species were combined, there were positive Pearson correlations with canopy cover for abundances of Aplodactylus arctidens ( $\mathrm{r}=0.24$ ) and Odax pullus ( $\mathrm{r}=0.21)$. Negative correlations 
with total macroalgal cover were found for abundances of Upeneichthys lineatus $(\mathrm{r}=-0.24)$ and Parapercis colias $(\mathrm{r}=-0.15)$.

\section{Western Cook Strait}

The first 2 CCA axes accounted for $13 \%$ and $9 \%$ of variation in the fish abundance data set, respectively (Fig. 2a). Three fishes (Cheilodactylus spectabilis, Notolabrus fucicola, and Odax pullus) were associated with negative scores on CAN1, which coincided with bedrock and boulder substrata, high topographic complexity, and occurrence of large brown macroalgae (Ecklonia radiata, Carpophyllum maschalocarpum, Marginariella boryana, Sargassum sinclairii, and Landsburgia quercifolia). Parapercis colias and Caesioperca lepidoptera were associated with fine substrata (gravel, shell rubble, and sand) and large bottom and canopy depths (Fig. 2b). Pseudolabrus miles was also associated with large bottom depths, but was less strongly associated with fine substrata. Parika scaber was associated with large canopy heights and Carpophyllum flexuosum. Although N. celidotus contributed $>70 \%$ of individuals counted, it was not strongly associated with any physical variable.

Total macroalgal canopy cover was positively correlated with abundances of Notolabrus fucicola $(\mathrm{r}=$ $0.40)$, Odax pullus $(\mathrm{r}=0.45)$, Parika scaber $(\mathrm{r}=0.29)$, Aplodactylus arctidens $(\mathrm{r}=0.19)$, and $N$. celidotus $(\mathrm{r}=0.25)$. Only the abundance of Parapercis colias demonstrated a strong negative correlation with canopy cover $(\mathrm{r}=-0.37)$.

\section{Stewart Island}

The first 2 axes of the CCA ordination accounted for $18 \%$ and $15 \%$ of variation, respectively (Fig. 3a). Pseudolabrus miles and Caesioperca lepidoptera were associated with high values of bottom depth, red macroalgae, Delisea pulchra, Himanthalia sp., and Gigartina sp., having high scores on both CAN1 and CAN2 (Fig. 3b). A group of fishes that occupied mainly shallow water (Latridopsis ciliaris, Latris lineata, Parika scaber, Notolabrus fucicola, and Odax pullus) were associated with bedrock and boulder substratum, high topographic complexity, and numerous large brown macroalgae (Fig. 3a). A third grouping of fishes occurred in the upper left quadrant of the plot, where Parapercis colias and Nemadactylus macropterus were associated with
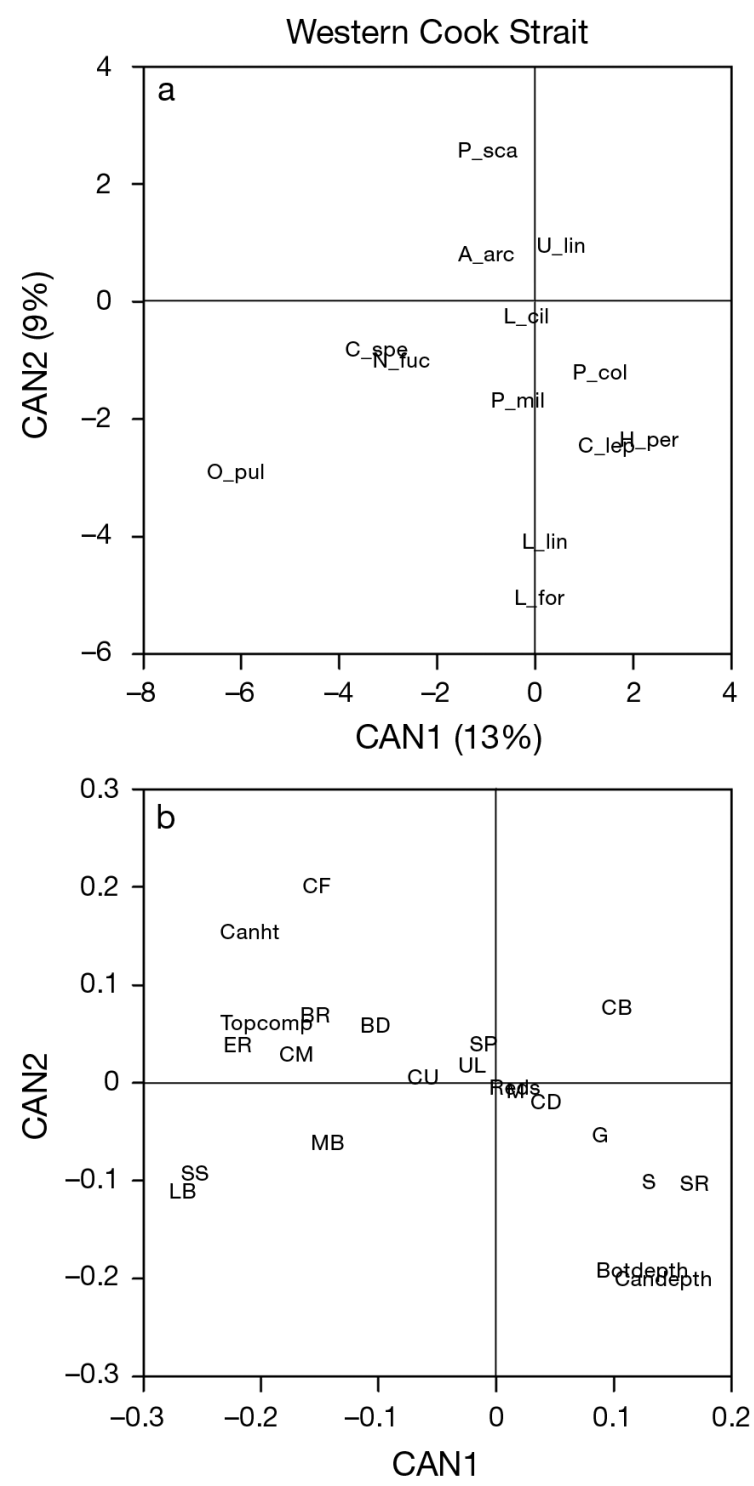

Fig. 2. Canonical correspondence analysis of (a) fishes and (b) habitat variables at western Cook Strait. L_for: Latridopsis forsteri; L_lin: Latris lineata; Reds: red macroalgae. See Fig. 1 legend for other fish species abbreviations, and Table 1 for substratum and biogenic habitat abbreviations

sand and cobbles, whereas Notolabrus celidotus was associated with Macrocystis pyrifera (which itself was associated with high values of canopy height).

Barrens vs. macroalgae comparison across sites within regions

At Bay of Plenty, abundances of Parma alboscapularis were twice as high in barrens habitat as in macroalgal-dominated habitat, although densities of 

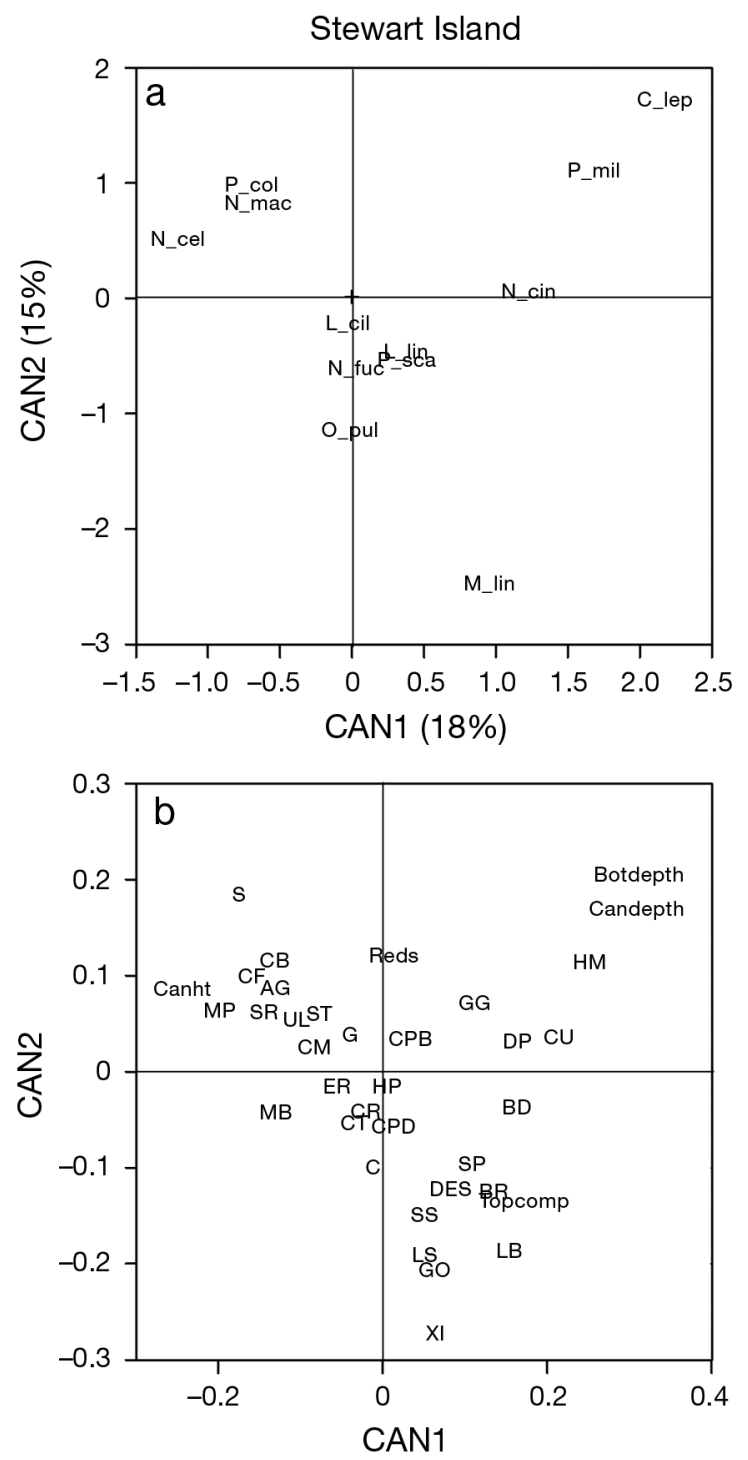

Fig. 3. Canonical correspondence analysis of (a) fishes and (b) habitat variables at eastern Stewart Island. L_lin: Latris lineata; M_lin: Mendosoma lineatum; N_cin: Notolabrus cinctus; Reds: red macroalgae; ST: Boltenia pachydermatina. See Fig. 1 legend for other fish species abbreviations, and Table 1 for substratum and biogenic habitat abbreviations

this fish in barrens were imprecisely estimated $(\mathrm{n}=5)$ (Fig. 4a). For other taxa (Chromis dispilus, Notolabrus celidotus, Cheilodactylus spectabilis, number of species), the differences in density between barrens and macroalgae were small (Fig. 4a). At western Cook Strait, Parapercis colias was roughly twice as abundant in barrens habitat as in macroalgae, whereas Odax pullus, Parika scaber, and Notolabrus celidotus were more abundant, and to a lesser extent, fish species richness was higher, in macroalgae (Fig. 4b).

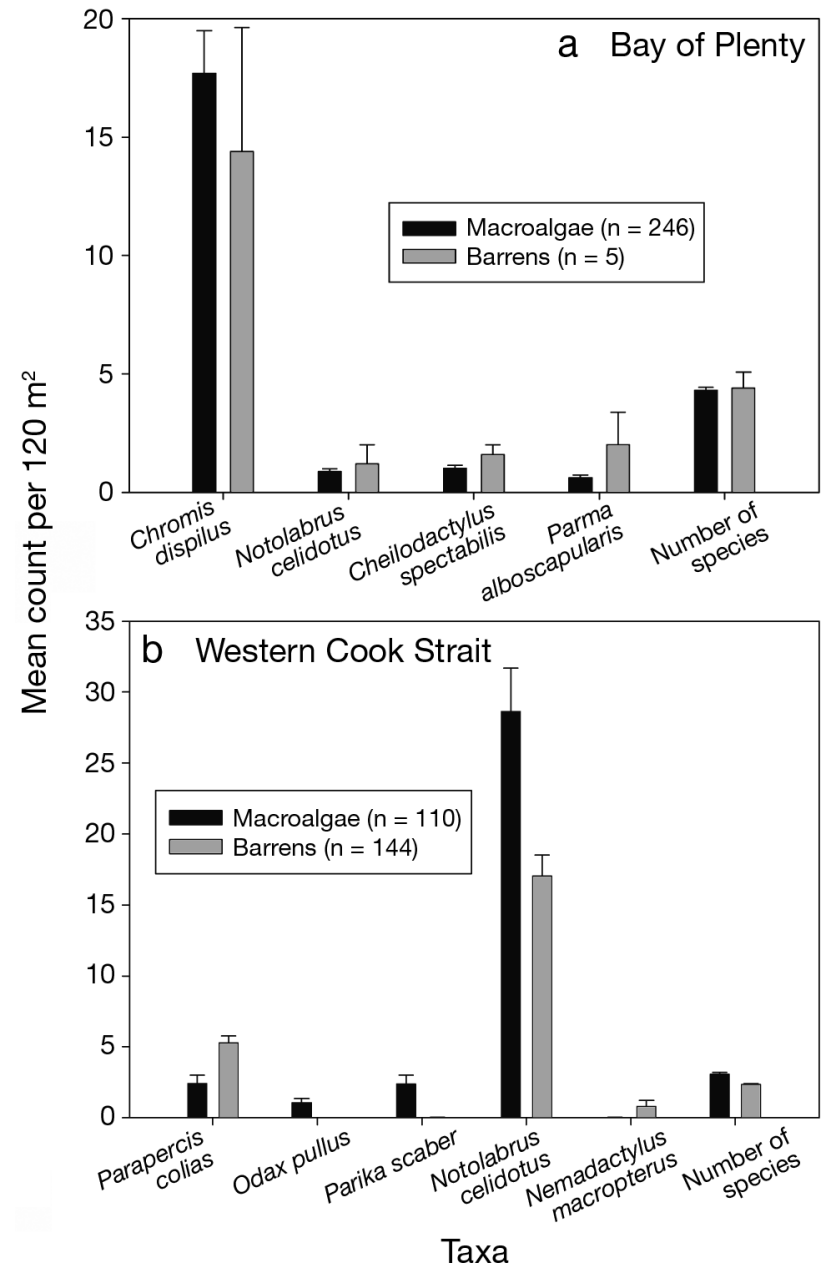

Fig. 4. Mean (+SD) abundances of fishes in survey transects comprising barrens and macroalgal habitats at (a) Bay of Plenty and (b) Port Hardy

Nemadactylus macropterus was also more abundant in barrens, but its density was very low. No barrens were recorded at Stewart Island.

\section{Macroalgal clearance experiments}

\section{Port Hardy}

The fish fauna near the Port Hardy clearance experiment comprised mainly Notolabrus celidotus (density: $2.4 \pm 1.0$ per $\left.120 \mathrm{~m}^{2}\right)$, Odax pullus $(0.9 \pm 0.3$ per $\left.120 \mathrm{~m}^{2}\right)$, and $N$. fucicola $\left(0.1 \pm 0.1\right.$ per $\left.120 \mathrm{~m}^{2}\right)$ (means $\pm \mathrm{SE}$, abundances pooled across all 3 samplings of the experiment). More fish were counted in transects in October (the second survey after clearances were conducted; data not shown) than in the previous 2 surveys. Before the clearances were 
established, visits to all quadrats were similar (Fig. 5). The numbers of visits by $N$. fucicola and especially Parapercis colias on each sampling occasion were highly variable. Mean numbers of visits by N. fucicola and P. colias to cleared quadrats were much greater than those to uncleared quadrats for the final survey, but both those estimates had very large SEs (Fig. $5 \mathrm{~b}, \mathrm{c}$ ). That trend only emerged in the final sam- pling for $N$. fucicola, but $P$. colias consistently visited cleared quadrats more than quadrats with an intact canopy. On Surveys 2 and 3, the fish faunas of the treatments were less distinct. Numbers of individuals visiting quadrats varied inconsistently with treatment (Fig. 5d), whereas number of species visiting was consistently higher in cleared quadrats (though the differences were always small) (Fig. 5e).
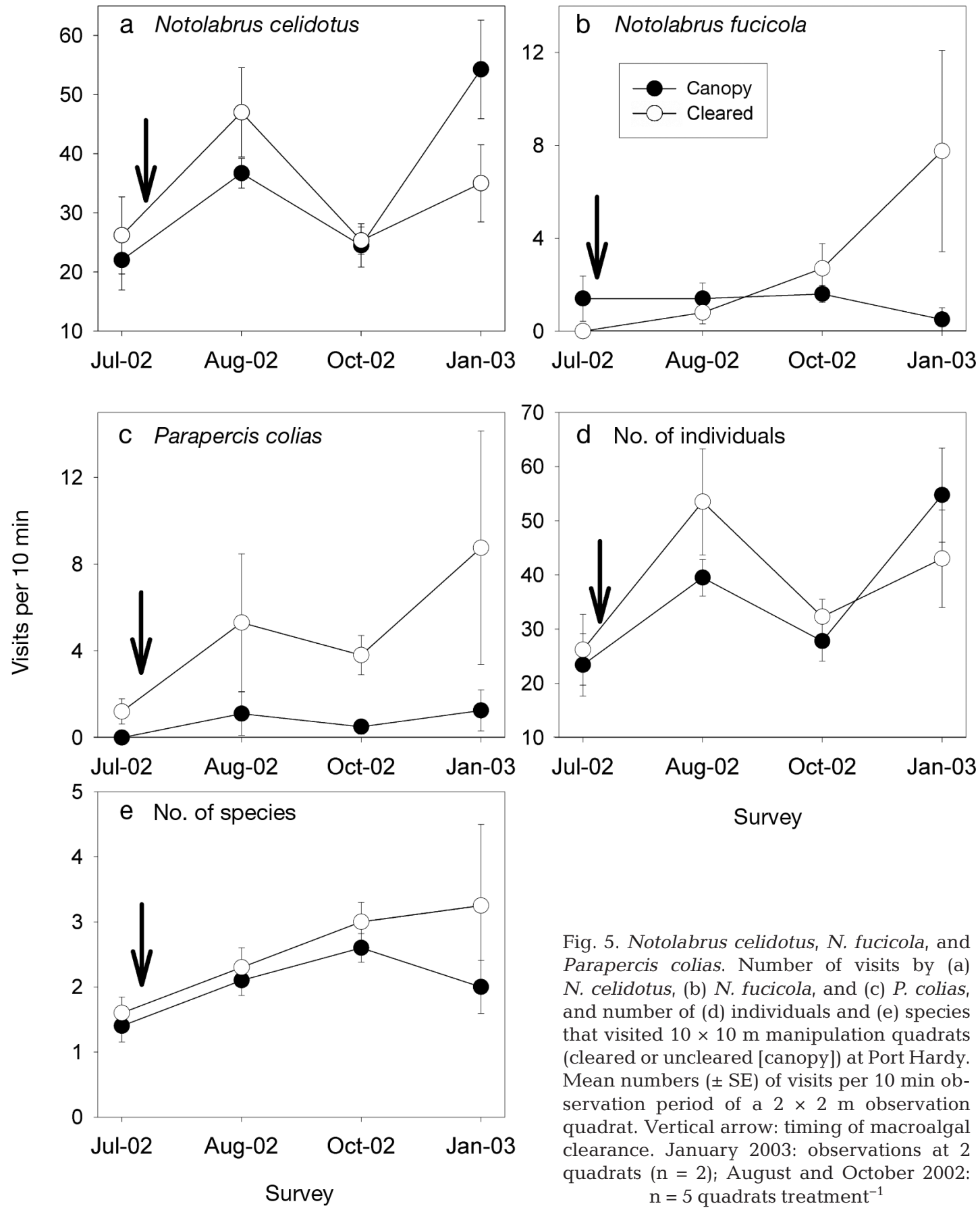

Fig. 5. Notolabrus celidotus, N. fucicola, and Parapercis colias. Number of visits by (a) N. celidotus, (b) N. fucicola, and (c) P. colias, and number of $(\mathrm{d})$ individuals and (e) species that visited $10 \times 10 \mathrm{~m}$ manipulation quadrats (cleared or uncleared [canopy]) at Port Hardy. Mean numbers $( \pm \mathrm{SE})$ of visits per $10 \mathrm{~min}$ observation period of a $2 \times 2 \mathrm{~m}$ observation quadrat. Vertical arrow: timing of macroalgal clearance. January 2003: observations at 2 quadrats $(\mathrm{n}=2)$; August and October 2002: $\mathrm{n}=5$ quadrats treatment ${ }^{-1}$ 
The sizes of fishes that visited cleared and uncleared quadrats were similar before, and on the first 2 occasions after, clearance, but larger fish visited clearances in October 2002 and January 2003 (Fig. 6).

\section{Rurima Shoals}

At Rurima Shoals, Bay of Plenty, all common species except Notolabrus celidotus made more visits to cleared areas than to adjacent areas with macroalgal canopies (Fig. 7a). Larger fish visited clearances more than uncleared areas (Fig. 7b), and that pattern was further emphasized when only permanently reef-associated fishes were considered (Fig. 7c). The main difference between cleared and control areas lay in the number of $N$. celidotus visiting; most of these were in the 10-15 cm size class. Length (mean $\pm \mathrm{SE}$ ) of fish visiting clearances was $21 \pm 0.9 \mathrm{~cm}(\mathrm{n}=107)$, whereas in areas with a macroalgal canopy, size was almost $14 \pm 0.5 \mathrm{~cm}$ (n = 35).

\section{Cable Bay}

Habitat manipulations at Cable Bay were characterized by high variability among replicates within treatments, and generally small effects (Fig. 8). Notolabrus celidotus were least active in the rocks-only treatment, but differences among the other 3 treatments were small (Fig. 8a). There was a large difference between the mean number of visits by $N$. celidotus for the mesh-control and the rocks-only

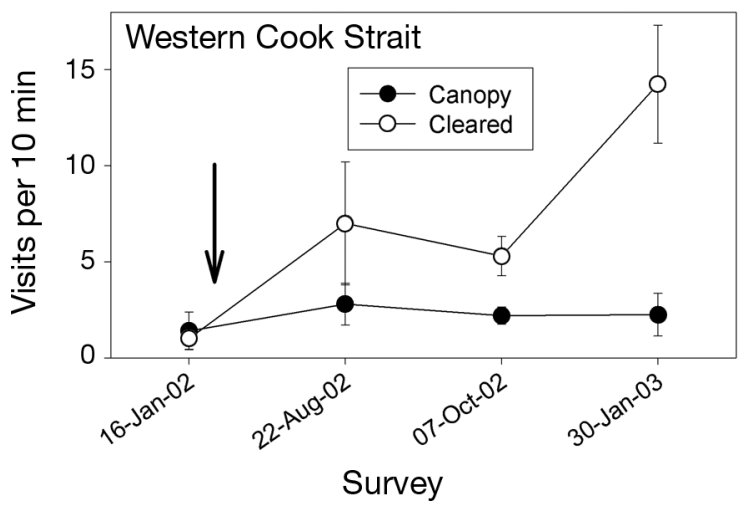

Fig. 6. Total number of visits per 10 min observation period by fish $>20 \mathrm{~cm}$ estimated total length (ETL) to cleared and uncleared (canopy) quadrats at Port Hardy. Vertical arrow: timing of macroalgal clearance. Means $\pm \mathrm{SE}$ treatment, which complicated the interpretation of the results for that species. Activity of Parapercis colias was characterized by high variability among replicate observations for the mesh and rocks-only treatments (Fig. 8b). The macroalgae-plus-rocks treatment received roughly half the number of visits by $P$. colias than the mesh-control and rocks-only treatments (Fig. 8b).
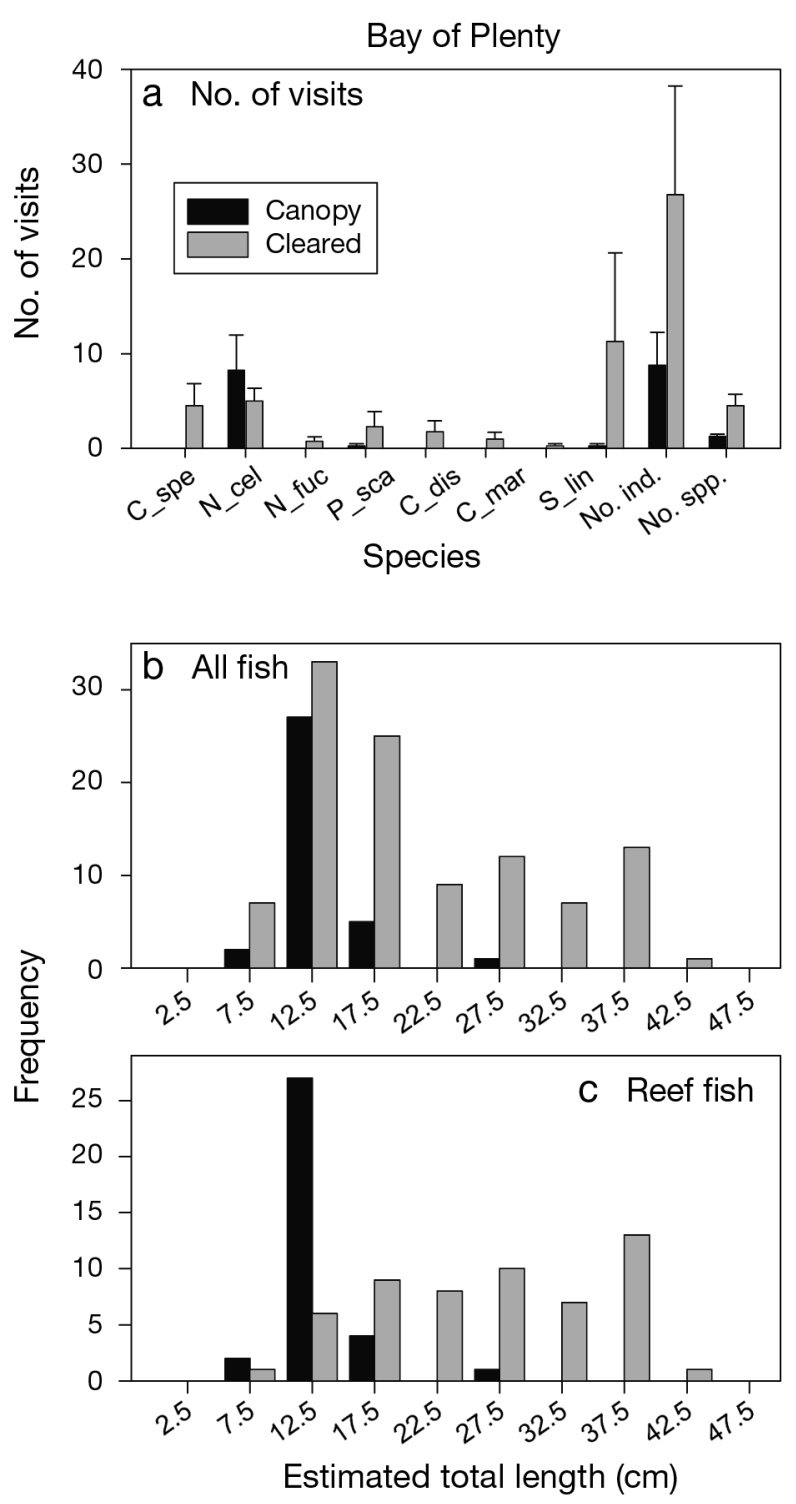

Fig. 7. (a) Number of visits by fish in 10 min observation periods to 2 cleared quadrats and adjacent uncleared areas (canopy) at Rurima Shoals (means $\pm \mathrm{SE}$ ). S_lin: Scorpis lineolatus. See Fig. 1 legend for other species abbreviations. (b,c) Estimated sizes of (b) all fish and (c) permanently reef-associated fish (i.e. excluding Chromis dispilus and S. lineatus) that visited quadrats either cleared of macroalgae, or in adjacent unmanipulated areas at Rurima Shoals. Data are from 10 min observations $(n=4)$ for each treatment 


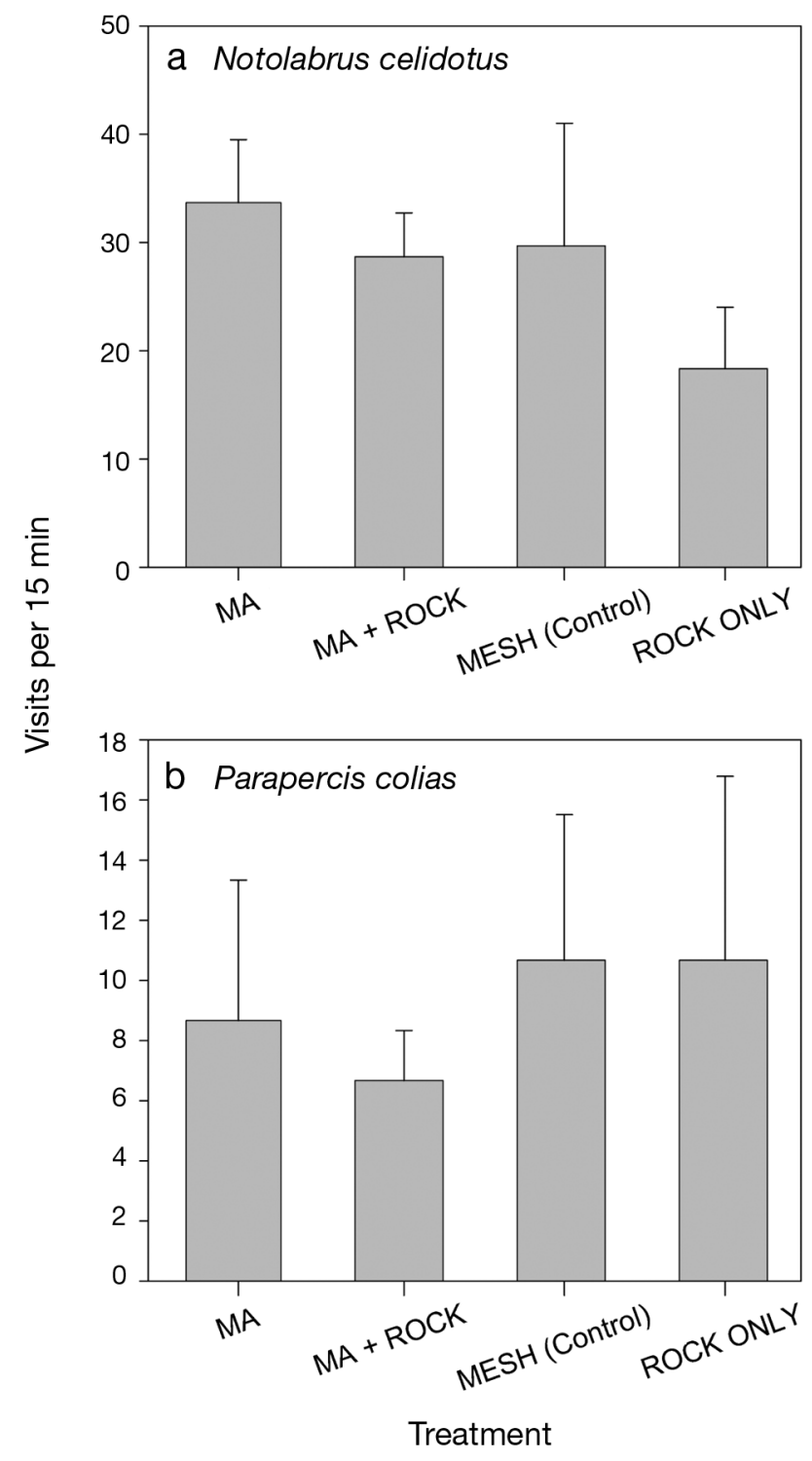

Fig. 8. Notolabrus celidotus and Parapercis colias. Number of visits in 15 min by (a) N. celidotus and (b) P. colias to $2 \times$ $2 \mathrm{~m}$ experimental squares of 4 treatments at Cable Bay: macroalgal addition (MA), macroalgal + boulder addition (MA + ROCK), mesh control for algal attachment (MESH (Control)), or boulder addition (ROCK ONLY). Means + SE, $\mathrm{n}=3$ replicate quadrats treatment ${ }^{-1} ; 1$ observation by SCUBA diver per quadrat

For both Parapercis colias and Notolabrus celidotus, modal sizes were slightly larger in the Carpophyllum flexuosum addition treatments (Fig. 9); differences among the other treatments were small. The proportion of small (0 to $5 \mathrm{~cm}$ ) N. celidotus was highest in the mesh treatment, whereas there were more large $(>20 \mathrm{~cm}$ ) individuals in the Carpophyllum spp. treatment.

\section{DISCUSSION}

Our sampling has extended the geographic range over which links between fish abundance and habitat features have been investigated within New Zealand. The data broadly support a number of previously described associations between particular fishes and habitat features in northeastern New Zealand. Patterns were often consistent among regions for common species (Table 2), but there were exceptions. We consider these patterns in more detail below.

Previous research has established that macroalgae influence recruitment and feeding of fishes, in northeastern New Zealand (Jones 1984, 1988, Choat \& Ayling 1987), and elsewhere (e.g. Levin \& Hay 1996). In the present study there were consistent, clear, links between the abundances of herbivores of brown macroalgae, such as Odax pullus, and macroalgal cover. Other previous research has suggested that several fishes recruit to macroalgal stands, where they feed on small invertebrates that associate with macroalgal fronds, e.g. Notolabrus celidotus (Jones 1984) and Parika scaber (Kingsford \& Milicich 1987). In the survey of western Cook Strait sites, $N$. celidotus and $P$. scaber were associated with high covers of Carpophyllum flexuosum. This result, however, stemmed from a single locality, Chetwode Islands. Aside from its high cover of macroalgae, this site was also the most current-swept of the localities we sampled in western Cook Strait. This raises the possibility that high larval supply was confounded with high macroalgal cover. Different patterns in occurrence of habitat and fishes might also confound correlational approaches. For example, the dominant macroalga Ecklonia radiata occurs extensively on reefs below $8 \mathrm{~m}$ in Bay of Plenty, potentially obscuring correlations with algal-associated fishes that occur mainly in shallow water, such as $O$. pullus. Experimental clearances of macroalgae elicited clearer responses.

Seasonal effects may have influenced the outcomes of our experiments. The effects of experimental clearances of macroalgae at Cook Strait (where we resampled experiments repeatedly) were clearest in summer. That effect was primarily owing to the higher numbers of visits by Notolabrus fucicola to clearances, and higher numbers of visits by $N$. celidotus to uncleared areas, in the January (summer) observations; activity of Parapercis colias was consistent throughout the experiment. The fish observations of Kingett \& Choat (1981), Andrew \& Choat (1982), and Choat \& Ayling (1987) were all carried 
Parapercis colias
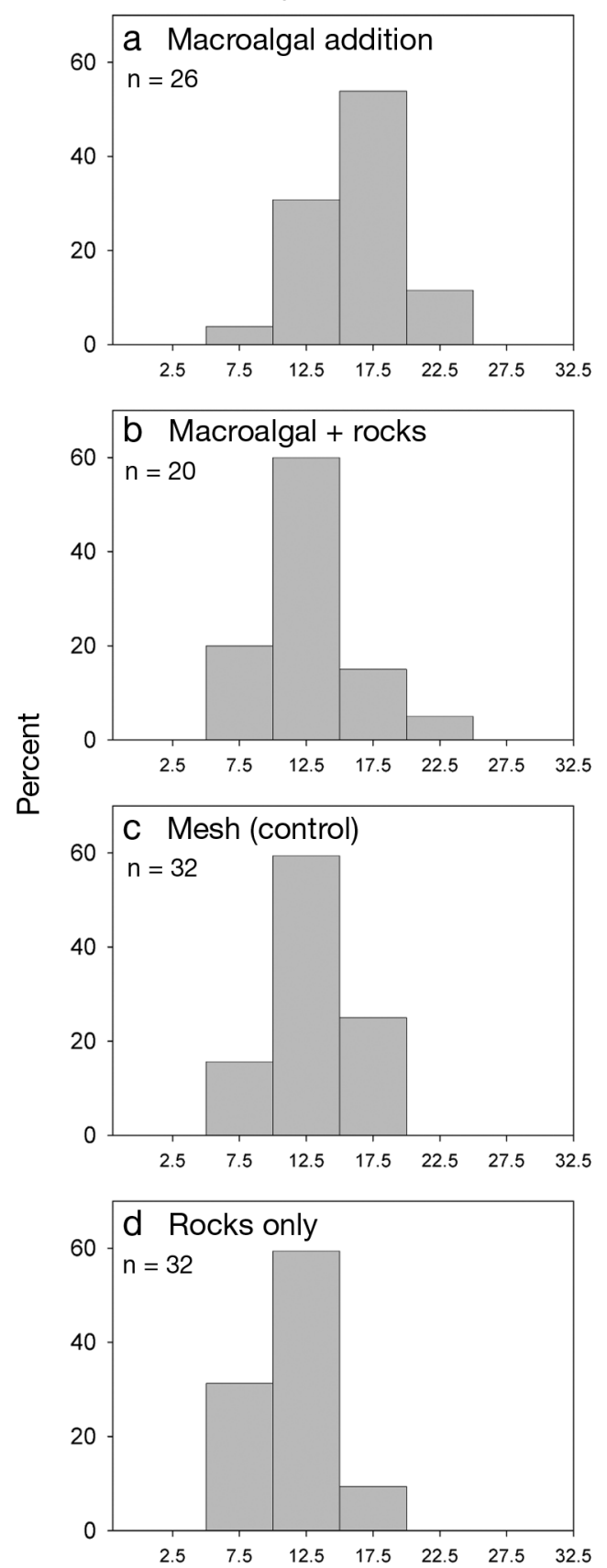

Notolabrus celidotus
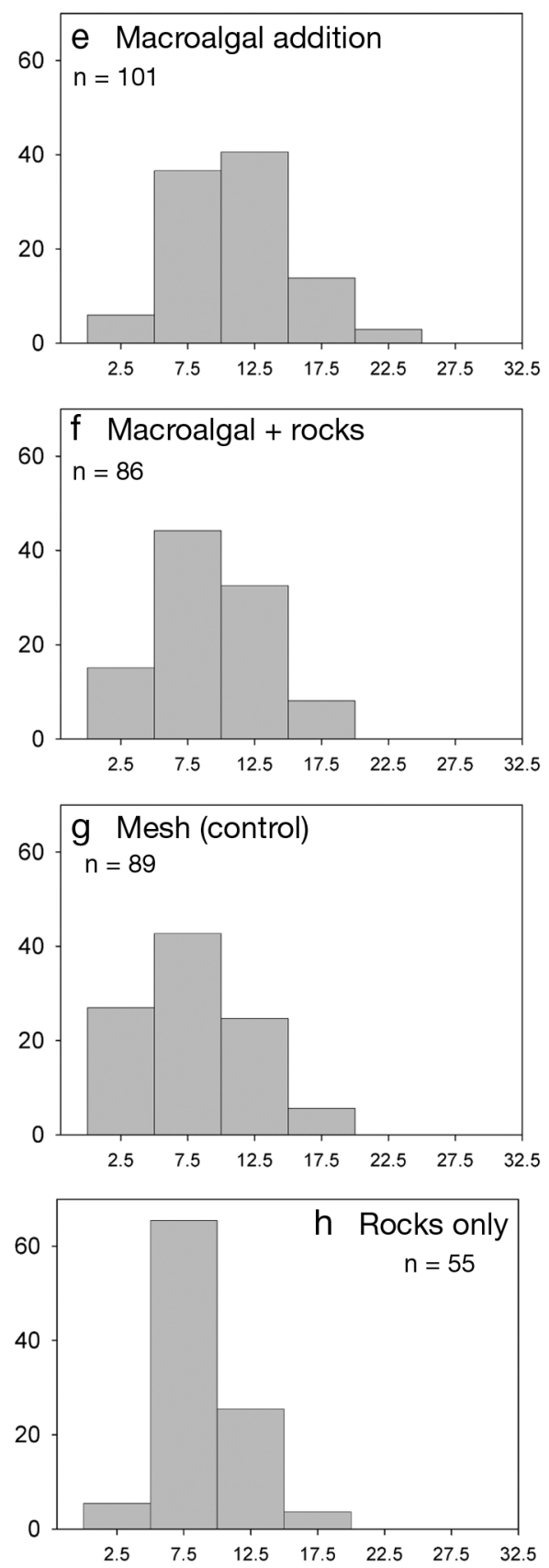

Estimated total length $(\mathrm{cm})$

Fig. 9. Notolabrus celidotus and Parapercis colias. Sizes of (a-d) P. colias and (e-h) N. celidotus in 15 min observations of $2 \times$ $2 \mathrm{~m}$ experimental squares of 4 treatments at Cable Bay from January 2008 to April 2009: (a,e) macroalgal addition, (b,f) macroalgal + boulder addition, $(\mathrm{c}, \mathrm{g})$ mesh control for algal attachment, or $(\mathrm{d}, \mathrm{h})$ boulder addition. $\mathrm{n}=3$ replicate quadrats treatment $^{-1}$; 1 observation by SCUBA diver per quadrat

out in summer (January and February), whereas the canopy clearance of Syms \& Jones (1999) was monitored repeatedly over $>12$ mo. The magnitude of experimental effects in the first 3 of those studies may have been influenced by timing, which coincided with periods of recruitment or high activity. Associations between reef fishes and kelp canopies are often strongest when individuals are small, as 
Table 2. Habitat associations of abundant fishes in each of the 3 regions studied. na: not available

\begin{tabular}{|llll|}
\hline \multirow{2}{*}{ Habitat } & \multicolumn{2}{c}{ Region } & \\
\cline { 2 - 4 } & Eastern Bay of Plenty & Western Cook Strait & Eastern Stewart Island \\
\hline Shallow macroalgae & $\begin{array}{l}\text { Cheilodactylus spectabilis } \\
\text { Notolabrus celidotus }\end{array}$ & $\begin{array}{l}\text { Cheilodactylus spectabilis } \\
\text { Notolabrus fucicola }\end{array}$ & $\begin{array}{l}\text { Notolabrus fucicola } \\
\text { Odax pullus }\end{array}$ \\
& Girella tricuspidata & & Odax pullus \\
Barrens & na & Parapercis colias & na \\
Deeper reef & Chromis dispilus & Parapercis colias & Pseudolabrus miles \\
& Upeneichthys lineatus & Pseudolabrus miles & Caesioperca lepidoptera \\
Sand/reef edge & Parapercis colias & Parapercis colias \\
& & & Nemadactylus macropterus \\
\hline
\end{tabular}

fish frequently recruit from the plankton to macroalgal canopies. The major difference in summer in our Cook Strait experiments was the occurrence of more large carnivores in clearances, as previously observed in northeastern New Zealand (Choat \& Ayling 1987).

The macroalgal clearance experiment that we conducted in the Bay of Plenty demonstrated that the activity of most reef fishes was higher in cleared plots. This result is generally similar to the effect of kelp canopy in northeastern New Zealand as described by Choat \& Ayling (1987). Three benthic carnivorous species that contributed a large proportion of the visits to cleared areas in Choat \& Ayling (1987)-Parapercis colias, Upeneichthys lineatus, and Pagrus auratus - did not occur in our macroalgal clearances at Bay of Plenty, but the overall effect was similar to those found in those authors' northern study. Some species observed in clearances are not benthic carnivores (e.g. the planktivores Scorpis lineolatus and Chromis dispilus), suggesting that macroalgae affect the activity of some species independently of feeding.

Topographic complexity is well established as an important determinant of the abundance and survivorship of fishes (e.g. Friedlander \& Parrish 1998). This is likely because finely dissected habitats have refuges from predators, which may improve survivorship of small fish (e.g. Connell \& Jones 1991). In northern New Zealand, the abundance of Cheilodactylus spectabilis, Chromis dispilus, Notolabrus celidotus, Pempheris adspersa, and Scorpis violaceus are all understood to be positively associated with topographically complex habitats (Jones 1988). Analyses of surveys conducted at eastern Bay of Plenty failed to reveal the strong positive correlation of C. spectabilis (a large, diver-neutral, and relatively sedentary fish) with topographic complexity identi- fied in northeastern New Zealand (Leum \& Choat 1980, McCormick \& Choat 1987). Lower detectability of C. spectabilis by our counting method in boulder habitats is one explanation for the difference in findings between our multi-species study and focused studies on C. spectabilis from northern New Zealand. For other reef species, associations with low topographic complexity can be stronger (e.g. Ross et al. 2007). In the present study, 2 species (Upeneichthys lineatus and Parapercis colias) were associated with low topographic complexity reef edge habitats. (For $P$. colias, this pattern occurred at both the western Cook Strait and eastern Stewart Island regions). Such associations may stem from different feeding specializations or habitat requirements; $U$. lineatus frequently feeds in turf and sand habitats (Jones 1988), and sediments are a potential nocturnal habitat for $P$. colias (National Institute of Water and Atmospheric Research [NIWA] unpubl.).

The orthogonal manipulation of rocks and macroalgae at Cable Bay (in Tasman Bay) gave results slightly at odds with the association of smaller fish with macroalgae described by Jones (1984) and Choat \& Ayling (1987). We found that sizes of Parapercis colias and Notolabrus celidotus were greatest in the treatment comprising macroalgae alone, whereas Jones (1984) found small $N$. celidotus to be most strongly associated with macroalgae, and Choat \& Ayling (1987) found that larger carnivorous fishes were more abundant in barrens habitat. However, Parsons et al. (2003) documented large Pagrus auratus roaming over kelp forest. Such size-associated habitat effects may be domain-dependent, in that the area of barrens at Leigh was small at the time of the Parsons et al. (2003) study. Similarly, barrens habitat dominates the Tasman Bay coast, and the area of macroalgal habitat is very small. Our independent observations suggest that $N$. celidotus recruits to 
macroalgae on the barrens-dominated Tasman Bay coast, as found by Jones (1984), but we are uncertain of the exclusivity of that association, or the habitat affinities of $P$. colias in that region. Densities of both $P$. colias (e.g. Cole et al. 2007) and macroalgae are low in Tasman Bay (www.doc.govt.nz/upload/documents/ conservation/marine-and-coastal/marine-protectedareas/horoirangi-mr-brochure-06.pdf; accessed 13 October 2011), and the spatial disjunction of greatest abundances of Parapercis colias (most abundant near the reef edge; NIWA unpubl.) and macroalgae (most abundant at $<2$ m depth near Nelson; Shears \& Babcock 2007) mean that the real-world significance of that interaction in Tasman Bay is limited.

Natural disturbances to macroalgal habitats may occur at much larger scales than those used in the present study. Natural clearances of Ecklonia radiata canopies (the dominant habitat-forming alga in northeastern New Zealand; Schiel 1988) may be up to thousands of $\mathrm{m}^{2}$ (e.g. Cole \& Babcock 1996, Cole \& Syms 1999, T. Haggitt, University of Auckland's Leigh Marine Laboratory, unpubl. data). The spatial scale of our experimental units is therefore toward the lower end of the range of natural disturbances to E. radiata (Cole \& Babcock 1996). We anticipate that only 'press' disturbances, via processes such as long-term reductions in water clarity (for species lacking surface canopies; Krause-Jensen et al. 2007), increased sedimentation (Airoldi \& Cinelli 1997), or elevated densities of grazers (cf. Babcock et al. 1999) would lead to persistent changes in the faunas of reefs occupied by Ecklonia forests. Alternatively, stands of Carpophyllum flexuosum in wavesheltered waters may seldom undergo disturbance, as they comprise large, old individuals (Cole et al. 2001). The process underlying clearances is likely to be wave action, rather than grazing (Cole \& Haggitt 2001). Where Macrocystis pyrifera occurred at Stewart Island, it formed a narrow band of width 10 to $20 \mathrm{~m}$ around the shore, suggesting that the $10 \times 10 \mathrm{~m}$ canopy clearances we established there were relevant to the occurrence patterns of that macroalga, but the extents of, and spatial patterns of disturbance regimes to, $M$. pyrifera stands are poorly known.

The ambits of organisms are also relevant in considering the spatial scale of clearances (Raffaelli \& Moller 2000). Both Parapercis colias and Notolabrus fucicola, whose modes of occurrence are the reef edge and areas $<8 \mathrm{~m}$ depth respectively, were observed in cleared quadrats tens of meters from their typical habitats. We are uncertain regarding whether presence of divers influenced those occurrences, but the movement ranges of some reef fishes are potentially large (e.g. Latridopsis ciliaris; Francis 1981), and P. colias and N. fucicola at least modified their activities to include habitat clearances separated by tens of meters of contiguous macroalgal habitat. N. celidotus were strongly canopy-associated and unlikely to reach the inner areas of the clearance quadrats, where our observation quadrats were placed. The durations of our canopy-clearance experiments were poorly suited to resolving ontogenetic shifts in habitat associations, and their timing may thus not document the closest associations, and greatest effects, of macroalgal canopies on fishes.

Our survey counts are potentially influenced by variability in (1) time of day of the sampling, and (2) season. We consider that our data are unlikely to be influenced by time of day because all of our counts were done in the middle part of the day, well after sunrise and well before sunset. Our surveys of the 3 regions were not done at the same time of the year, but are unlikely to have been influenced by seasonal migrations. Very few New Zealand fishes are known to undertake migrations among locations seasonally, or to move among depth strata seasonally. The only teleost species undertaking such movements of which we are aware is Latridopsis ciliaris, which undertakes long-distance migrations (Francis 1981). It is possible that our February (summer) counts of that species in Bay of Plenty may have been low compared to winter (June and July), when such fish were netted near Cape Runaway (Francis 1981), but that species did not feature in our experiments in that region. We consider uneven detectability of fish among habitats to be unlikely because those persons who counted fish were experienced.

\section{SUMMARY AND CONCLUSIONS}

Our surveys identified distinct associations between fishes and habitat features in 3 widely spaced geographic regions. Habitat associations were frequently consistent among regions for abundant species: for example, Notolabrus fucicola was consistently associated with shallow macroalgae, Pseudolabrus miles was most abundant on deeper reefs, and Parapercis colias characterized barrens and reef edge. Larger fish were associated with barrens, whereas smaller fish were associated with macroalgae. Experimental manipulations demonstrated geographically consistent causal effects (though small in magnitude) of macroalgae. Habitat associations are, however, expressed in the context of broad, species-specific, depth ranges. 
Acknowledgements. This project was funded by the Foundation for Research, Science, and Technology, under contracts C01X0004 and C01X0209. Thanks to N. Andrew, A. MacDiarmid, and J. McLean for administration; the skippers R. and L. Phillips, B. and L. Bird, and P. Pascoe; S. Brown, P. Marriott, and M. Page, who assisted with fieldwork; and the referees R. B. Taylor, D. Morrisey, N. Gust, and especially D. Parsons for helpful comments on the manuscript.

\section{LITERATURE CITED}

Airoldi L, Cinelli F (1997) Effects of sedimentation on subtidal macroalgal assemblages: an experimental study from a Mediterranean rocky shore. J Exp Mar Biol Ecol 215: 269-288

> Andrew NL, Choat JH (1982) The influence of predation and conspecific adults on the abundance of juvenile Evechinus chloroticus (Echinoidea: Echinometridae). Oecologia 54:80-87

Ayling AM (1978) Okakari Point to Cape Rodney Marine Reserve: a biological survey. Leigh Marine Laboratory, University of Auckland, Leigh

Babcock RC, Kelly S, Shears NT, Walker JW, Willis TJ (1999) Changes in community structure in temperate marine reserves. Mar Ecol Prog Ser 189:125-134

Carver RP (1993) The case against statistical significance testing, revisited. J Exp Educ 61:287-292

Choat JH, Ayling AM (1987) The relationship between habitat structure and fish faunas on New Zealand reefs. J Exp Mar Biol Ecol 110:257-284

> Cole RG, Babcock RC (1996) Mass mortality of a dominant kelp (Laminariales) at Goat Island, north-eastern New Zealand. Mar Freshw Res 47:907-911

Cole RG, Haggitt TR (2001) Dietary preferences of Evechinus chloroticus. In: Barker MF (ed) Echinoderms 2000. Swets \& Zeitlinger, Lisse, p 425-430

Cole RG, McBride GB (2004) Assessing impacts of dredge spoil disposal using equivalence tests: implications of a precautionary (proof of safety) approach. Mar Ecol Prog Ser 279:63-72

> Cole RG, Syms C (1999) Using spatial pattern analysis to distinguish causes of mortality: an example from kelp in north-eastern New Zealand. J Ecol 87:963-972

> Cole RG, Babcock RC, Travers V, Creese RG (2001) Distributional expansion of Carpophyllum flexuosum onto waveexposed reefs in north-eastern New Zealand. NZ J Mar Freshw Res 35:17-32

Cole RG, Syms C, Davey NK, Gust N and others (2007) Does breathing apparatus affect fish counts and observations? A comparison at three New Zealand fished and protected areas. Mar Biol 150:1379-1395

Connell SD, Jones GP (1991) The influence of habitat complexity on postrecruitment processes in a temperate reef fish population. J Exp Mar Biol Ecol 151:271-294

Ebeling AW, Hixon MA (1991) Tropical and temperate reef fishes: comparison of community structures. In: Sale PF (ed) The ecology of fishes on coral reefs. Academic Press, San Diego, CA, p 505-563

Edgar GJ, Moore PG (1986) Macro-algae as habitats for motile macrofauna. Monogr Biol 4:255-277

Francis MP (1981) Spawning migration of moki (Latridopsis ciliaris) off eastern New Zealand. NZ J Mar Freshw Res 15:267-273
Francis MP (1996) Geographic distribution of marine reef fishes in the New Zealand region. NZ J Mar Freshw Res 30:35-55

Francis MP, Hurst RJ, McArdle BH, Bagley NW, Anderson OF (2002) New Zealand demersal fish assemblages. Environ Biol Fishes 65:215-234

- Friedlander AM, Parrish JD (1998) Habitat characteristics affecting fish assemblages on a Hawaiian coral reef. J Exp Mar Biol Ecol 224:1-30

> Gerrodette T (2011) Inference without significance: measuring support for hypotheses rather than rejecting them. Mar Ecol 32:404-418

> Gust N, Choat JH, McCormick MI (2001) Spatial variability in reef fish distribution, abundance, size and biomass: a multi-scale analysis. Mar Ecol Prog Ser 214:237-251

Halpern BS (2003) The impact of marine reserves: do reserves work and does reserve size matter? Ecol Appl 13(Suppl):S117-S137

Johnson DW (2006) Predation, habitat complexity, and variation in density-dependent mortality of temperate reef fishes. Ecology 87:1179-1188

Jones GP (1984) Population ecology of the temperate reef fish Pseudolabrus celidotus Bloch and Schneider (Pisces: Labridae). I. Factors influencing recruitment. J Exp Mar Biol Ecol 75:257-276

Jones GP (1988) Ecology of rocky reef fish of north-eastern New Zealand: a review. NZ J Mar Freshw Res 22: 445-462

Jones GP, Andrew NL (1990) Herbivory and patch dynamics on rocky reefs in temperate Australasia: the roles of fish and sea urchins. Aust J Ecol 15:505-520

Jones GP, McCormick MI (2002) Numerical and energetic processes in the ecology of coral reef fishes. In: Sale PF (ed) Coral reef fishes. Dynamics and diversity in a complex ecosystem. Elsevier Science, Sydney, p 221-238

Jones GP, McCormick MI, Srinivasan M, Eagle JV (2004) Coral decline threatens fish biodiversity in marine reserves. Proc Natl Acad Sci USA 101:8251-8253

Kingett PD, Choat JH (1981) Analysis of density and distribution patterns in Chrysophrys [Pagrus] auratus (Pisces: Sparidae) within a reef environment: an experimental approach. Mar Ecol Prog Ser 5:283-290

Kingsford MJ, Milicich MJ (1987) Presettlement phase of Parika scaber (Pisces: Monacanthidae): a temperate reef fish. Mar Ecol Prog Ser 36:65-79

Krause-Jensen D, Middelboe AL, Carstensen J, Dahl K (2007) Spatial patterns of macroalgal abundance in relation to eutrophication. Mar Biol 152:25-36

Leum LL, Choat JH (1980) Density and distribution patterns of the temperate marine fish Cheilodactylus spectabilis (Cheilodactylidae) in a reef environment. Mar Biol 57: 327-337

> Levin PS, Hay ME (1996) Responses of temperate reef fishes to alterations in algal structure and species composition. Mar Ecol Prog Ser 134:37-47

> McCormick MI, Choat JH (1987) Estimating total abundance of a large temperate-reef fish using visual striptransects. Mar Biol 96:469-478

Nagelkerken I, Van der Velde G, Gorissen MW, Meijer GJ, Van't Hof T, den Hartog C (2000) Importance of mangroves, seagrass beds and the shallow coral reef as a nursery for important coral reef fishes, using a visual census technique. Estuar Coast Shelf Sci 51:31-44

Ojeda FP, Dearborn JH (1991) Feeding ecology of benthic mobile predators: experimental analyses of their influ- 
ence in rocky subtidal communities of the Gulf of Maine. J Exp Mar Biol Ecol 149:13-44

Parsons DM, Babcock RC, Willis TJ, Hankin RKS, Aitken JP, O'Dor RK, Jackson GD (2003) Snapper Pagrus auratus (Sparidae) home range dynamics: acoustic tagging studies in a marine reserve. Mar Ecol Prog Ser 262:253-265

Pérez-Matus A, Shima JS (2010) Disentangling the effects of macroalgae on the abundance of temperate reef fishes. J Exp Mar Biol Ecol 388:1-10

Peterson $\mathrm{CH}$, Summerson HC, Thomson E, Lenihan HS and others (2000) Synthesis of linkages between benthic and fish communities as a key to protecting essential fish habitat. Bull Mar Sci 66:759-774

Raffaelli DG, Moller H (2000) Manipulative field experiments in animal ecology: Do they promise more than they can deliver? Adv Ecol Res 30:299-338

Ross PM, Thrush SF, Montgomery JC, Walker JW, Parsons DM (2007) Habitat complexity and predation risk determine juvenile snapper (Pagrus auratus) and goatfish (Upeneichthys lineatus) behaviour and distribution. Mar Freshw Res 58:1144-1151

Ruitton SP, Francour P, Boudouresque CF (2000) Relationships between algae, benthic herbivorous invertebrates and fishes in rocky sublittoral communities of a temperate sea (Mediterranean). Estuar Coast Shelf Sci 50:217-230

Schiel DR (1988) Algal interactions on shallow subtidal reefs in northern New Zealand: a review. NZ J Mar Freshw Res 22:481-489

Schiel DR (1990) Macroalgal assemblages in New Zealand: structure, interactions, and demography. Hydrobiologia 192:59-76

Editorial responsibility: Janet Ley,

St. Petersburg, Florida, USA
Schiel DR, Foster MS (2006) The population biology of large brown seaweeds: ecological consequences of multiphase life histories in dynamic coastal environments. Annu Rev Ecol Evol Syst 37:343-372

Schiel DR, Hickford MJ (2001) Biological structure of nearshore rocky subtidal habitats in southern New Zealand. Science for Conservation 182. New Zealand Department of Conservation, Wellington

Shears NT, Babcock RC (2007) Quantitative description of mainland New Zealand's shallow subtidal reef communities. Science for Conservation 280. New Zealand Department of Conservation, Wellington

Smale MJ, Buxton CD (1985) Aspects of the recreational skiboat fishery off the Eastern Cape, South Africa. S Afr J Mar Sci 3:131-144

Syms C, Jones GP (1999) Scale of disturbance and the structure of a temperate fish guild. Ecology 80:921-940

Taylor RB (1998) Density, biomass and productivity of animals in four subtidal rocky reef habitats: the importance of small mobile invertebrates. Mar Ecol Prog Ser 172: 37-51

Thompson SM (1981) Fish of the marine reserve. A guide to the identification and biology of common coastal fish of north-eastern New Zealand. Leigh Marine Laboratory, University of Auckland, Auckland

Tupper M, Boutilier RG (1997) Effects of habitat on settlement, growth, predation risk and survival of a temperate reef fish. Mar Ecol Prog Ser 151:225-236

Turner SJ, Thrush SF, Hewitt JE, Cummings VJ, Funnell G (1999) Fishing impacts and the degradation or loss of habitat structure. Fish Manag Ecol 6:401-420

Submitted: February 22, 2011; Accepted: December 15, 2011 Proofs received from author(s): March 6, 2012 